\title{
Assessment of External Supports for Harvesting Artisanal Galda (Macrobrachium Rosenbergii de Man) Fisheries from the Sundarbans Mangrove Ecosystem in Bangladesh
}

Biplab Kumar Shaha ${ }^{1}$, Md. Mahmudul Alam ${ }^{2}$, H. M. Rakibul Islam ${ }^{3}$, Lubna Alam ${ }^{4}$, Khan Kamal Uddin Ahmed ${ }^{5}$, Mazlin Mokhtar ${ }^{6}$

${ }^{1}$ Fisheries and Marine Resource Technology Discipline, Khulna University, Bangladesh

${ }^{2}$ Doctoral Student, Institute for Environment and Development (LESTARI), National University of Malaysia (UKM), Malaysia

${ }^{3}$ Scientific Officer, Bangladesh Fisheries Research Institute, Shrimp Research Station, Bagerhat, Bangladesh

${ }^{4}$ Post-Doctorate Fellow, Institute for Environment and Development (LESTARI), National University of Malaysia (UKM), Malaysia

${ }^{5}$ Chief Scientific Officer, Bangladesh Fisheries Research Institute. Shrimp Research Station, Bagerhat, Bangladesh

${ }^{6}$ Professor, Institute for Environment and Development (LESTARI), National University of Malaysia (UKM), Malaysia

\section{Citation Reference:}

Shaha, B.K., Alam, M.M., Islam, H.M.R., Alam, L., and Mokthar, M. 2015. Assessment of External Supports for Harvesting Artisanal Galda (Macrobrachium rosenbergii de Man) Fisheries from the Sundarbans Mangrove Ecosystem in Bangladesh. International Journal of Lakes and Rivers. Vol.8(1), pp. 1-23. [Online Link]

This is a pre-publication copy.

The published article is copyrighted by the publisher of the journal.

\footnotetext{
*Corresponding author, email: rony000@gmail.com
} 


\title{
Assessment of External Supports for Harvesting Artisanal Galda (Macrobrachium Rosenbergii de Man) Fisheries from the Sundarbans Mangrove Ecosystem in Bangladesh
}

\begin{abstract}
The study was conducted through 24 individual surveys in the SME of Bangladesh covering 16 river/canals and 32 locations (one-third area) of the Sundarbans by direct interviews of randomly selected 1,989 fishermen from 545 non-mechanized boats and 1,428 active gears from eight types of gear. The source of credit, agreement of Dadan, variability in prices, profit distribution agreement between boat/gear owner and the fishing labour, catch volume, and the relation between the fisher and the landing centers (i.e., intimacy and expected market prices) were found to be determinant factors in determining the place for landings of the harvested catches in the study area. There was access of fishers to the formal credit markets (i.e. scheduled banks or cooperatives) at $13 \pm 2.83$ (11-15) $\%$ interest. However, the rate of interest offered by the NGOs was significantly higher (mean: $45 \pm 31$, range: $18-76 \%$ ) than the bank rates. A number of formalities were found to inhibit fishers to receive credit from Banks and NGOs. About 60-100\% of the value of Galda catch, after covering the operational costs, was taken by the boat and gear owner. The share of the labor also varied by the type of work performed (catching, drying, transporting, cooking on boat etc.). The average prices of Galda at landing centers are varied from BDT 290 to $750 \mathrm{~kg}^{-1}$. The average prices of Galda at landing centers and in international markets were BDT 290 and $750 \mathrm{~kg}^{-1}$, respectively in 2006. The Department of Forest, being the legal authority in the management of aquatic resources inside the waters of the SME of Bangladesh should care the sustainable management of small-scale fisheries to ensure a sustainable growth rate of Galda, and protect over exploitation. Proper and easy financial and credit supports is needed for the economic betterment of the small fishers. Hence the findings and the recommendations of this study is supposed to be helpful for policy makers in improving the current status of Galda fishery and relevant human livelihood as well as conserving the Sundarbans Mangrove Ecosystem ecosystem.
\end{abstract}

Key word: Macrobrachium rosenbergii; Sundarbans Mangrove Ecosystem; Microcredit; Fish Market

\section{Introduction}

The reverie giant prawn Macrobrachium rosenbergii, locally called as Galda, is one of the high valued crustaceans in Bangladesh and also a highly valued product in international markets; almost all prawns are therefore exported, particularly to the USA, Japan, and Europe. Traditionally, freshwater prawns have been caught wild in ponds and marshes (Gain, 1998) through artisanal fisheries across the country. It has been widely distributed in all types of freshwater habitats and also migrates to the costal saline estuaries for breeding.

The species is cultivated across Bangladesh in freshwater ponds for export. Between the late 1970s and the mid-1980s, a few pioneering farmers in Fakirhat Upazila (sub-district) in Bagerhat district developed Galda farming technology in small rice-fields using mainly rain water and peripheral mud embankments (Rutherford, 1994). In 1976 Bangladesh exported a total of $3,800 \mathrm{mt}$ of shrimps and prawns, and in just twenty years this grew 
eightfold to $31,500 \mathrm{mt}$. Of this total, approximately $85 \%$ were cultured, half of them are from fresh water. These exports earned 248 million dollars, equivalent roughly to a $3 \%$ share of the world's total shrimp/prawn exports (Vannuccini, 1999). Bangladesh exported 46,533 mt of prawn and shrimp in 2005 valued at US\$ 378 million in which $25-30 \%$ was contributed by prawn (DoF, 2006). This figure is expected to rise with the increasing expansion of freshwater prawn cultivation into new area of Mymensingh district in the north-central part of Bangladesh (Ahmed et al., 2008). The total area under cultivation nationwide is estimated to be around 30,000 ha (Willams, 2003). Assuming that the royalty rate is only $12.5 \%$ of the gross value of the products, it can be calculated that the gross value of the fish products in 1990-91 was BDT 112 million (US\$ 2.8 million) (Islam, 2007).

The Sundarbans, a cluster of islands with an approximate area of 10,000 square kilometers in Bangladesh and India, is the largest mangrove forest in the world (Rahman et al., 2003). It is located at the southern extremity of the Ganges delta bordering the Bay of Bengal along the southwest of Bangladesh and southeast of India. About $60 \%$ of the Sundarbans are within Bangladesh territory, known as the Sundarbans Reserved Forest (SRF) or Sundarbans Mangrove Ecosystem (SME), is located at the southwest part adjacent to the district of Bagerhat, Khulna and Satkhira. Ecologically the SRF is classified in to three ecological zones- i) freshwater zone along the Eastern part within Sarankhola range; ii) moderately saline zone along the middle-southern part within Khulna range and iii) high saline zone along the south-western part within Satkhira range (Karim, 1994). Mangrove ecosystems act as nursery grounds and provide refuges for many species of fish, crustacean and mollusks (Ronnback, 2001; Ronnback, 1999). There is a positive correlation between mangrove area and shrimp/fish catches (Primavera, 1995 and 1997). It has been estimated that every hectare of mangrove generates upwards of $450 \mathrm{~kg} \mathrm{ha}^{-1}$ of marine catch (WB, 2006). The continued existence and functionality of the Sunderbans mangrove forest is of critical importance to the entire marine fishery of the Bay of Bengal. An estimated $80 \%$ of the Indian fish catch from the Ganges and Brahmaputra river deltas originates in the Sundarbans mangroves (Hinrichsen, 1998), while others estimate that perhaps as much as $90 \%$ of commercial fish catches in the Bay of Bengal rely on Bangladesh's Sundarbans Reserved Forest as a nursery area (Rouf and Jensen, 2001). About 20\% of Bangladesh's coastal communities rely exclusively on wild fisheries for their income (Barkat and Roy, 2001). About BDT 30 million (US\$ 750,000) per annum is earned from 60 million $\mathrm{kg}$ of shrimps, mainly tiger prawns, from the Sundarbans and other coastal mangrove areas of Bangladesh (DoF, 2005; BBS, 2005).

A large number of fishing community is involved in Galda fishing from the SME. An average of 67,195 boats with 165,270 fishermen annually visits the Sundarbans and fish for their livelihood (DoF, 2008a). Recent data reveals that the collection of "seed" prawns involves about 25,000 men, women and children (DoF, 2008b). Shell collection also contributes to the employment of young boys and girls (about 550 permit issues each engaging 3-4 people each year). The number of shell collectors increases during the winter tourist season (Rahman et al., 2003; Giasuddin, 2002). While there is great potential for increasing family incomes through engaging in prawn cultivation, a number of factors might contribute to the vulnerability of prawn farmers including increased production costs, poor institutional support, and inadequate extension services (Ahmed, 2002); on the other hand, those factors are less effective in wild fishery. With this view, it is essential to understand the external facilities available for harvesting Galda from SME. 
However, no information is available on the Galda fishery in particular in the above context in the SME. This study, therefore, was aimed at to assess the available marketing and financial supports for Galda (Macrobrachium rosenbergii) fishery from the Sundarbans mangrove ecosystem of Bangladesh. The findings will benefit fishers, researcher and policymakers.

\section{Literature Review}

The existing literature on aquatic species in Bangladesh are by large focused on the farming aspects rather than fishery (Halim et al., 2001; Ling et al., 1999; Huda et al., 2002; Aftabuzzaman, 1998; Thomas et al., 2001; Bhattacharya et al., 1999a and 1999b; Leung and Sharma, 2001; Ling et al., 2001; Shang et al., 2001). Most of the economic analyses carried out in the past in Bangladesh were concentrated on aquaculture production of Galda or Bagda shrimps (Shah et al., 2000; Ito, 2002; Ahmed et al., 2008; Alam et al., 2007; Ahmed, 2001; UNEP, 1999; BCAS, 2001; Quddus et al., 2001; Manju, 1996). Exploration of the Sundarban mangroves dates back to the 16th century (Rollet, 1981), a large bulk of published literature exists on the Sundarbans of both India (Naskar and Guha Bakshi, 1987; Chaudhuri and Choudhury, 1994; Guha Bakshi et al., 1999) and Bangladesh (Seidensticker et al., 1991; Hussain and Acharya, 1994; Islam and Wahab, 2005) covering many aspects of their habitat characteristics, flora, fauna (particularly fisheries), utilization and management. However, little is known about the functional aspects of this ecosystem.

Alam (2001) described three different levels of fish markets including Galda marketing. A detailed description of Galda marketing is available in Tsai and Ali (1997). Rutherford (1994) outlined the marketing structure of the freshwater prawn industry, together with the financial flows with five layers of agency. At the top are fish-processing and export companies located in Khulna town. Below them are the commission agents who buy prawns from local middlemen (Depot Maliks) and sell them on to the companies for a commission: many of these commission agents are wealthy businessmen in Khulna who have easy access to bank loans. The third layer is composed of the Depot Maliks (storage-owners-cum-fishbuyers) themselves, who purchase prawns from local producers and sell them on to commission agents. It is impossible to miss their presence, since this is registered in almost all the local prawnfarming markets in Bagerhat and Khulna by the large signboards of the individual Depot Maliks bearing huge, garish pictures of prawns and shrimps. They often buy prawns directly from prawn farmers, but there are also local small traders called Forias who mediate between local farmers and Depot Maliks (Ito, 2002).

Although there are several internationally recognized grading system (counts/lb) for Galda marketing (FAO, 2004), it is absent in the primary markets at local levels mainly due to poor bargaining power of the fishers unlike mud crab prices (Zafar and Ahsan, 2006). Moreover, there is a little variation in selling prices due to transport costs and available marketing facilities. Locally all Galda catches from the SME are marketed at fresh condition. Quality maintenance facilities (ice or other processing facilities) in the SME are very poor. There is high risk of spoilage of the harvested catch if collector boats respond late. There is also a lack of knowledge about sound post-harvest practices (Zafar and Ahsan, 2006).

Like other fisheries product, Galda trading is characterized by several categories of fishermen and fishing enterprises with the share arrangement regime (Dastidar, 2001; Hussain et al., 1995; Coulter and Disney, 1987). There have a strong relationship between market demand for Galda and the supply of credit. There is a separate distribution channels 
for Galda marketing. Dastidar, (2001), Hussain et al., (1995) and Zafar and Ahsan, (2006) mentioned that mud crab and shrimp trading, other than fish, in the region has increasing consistently over the past few years, only due to higher demand for Galda in the international markets. European-union, Malaysia, Japan, USA and Singapore are the main markets for frozen Bangladeshi Galda. There seems to be significant fluctuation in the market prices of Galda due to the wide seasonal variations in the landings volume and seasonal demand by the export markets (Hill, 1984).

Bostock et al., (2004) also mentioned that the owners of small mechanized Galda fishing boats in Bangladesh do not have enough money to finance their journey to the sea. They have to borrow money from the moneylenders and the loan system is the same as the cultured shrimp production system. When these boats land on the shore the boat owners had to sell shrimps to their respective moneylenders or local traders at lower prices to compenset the interest on the borrowed money. The traders then sell the shrimps to the processing factories. The processing factories sell frozen shrimp of various categories sell out their products to the foreign buyers through brokers. Sometimes shrimps are supplied to the factories by depot owners. The moneylenders sell shrimp to the depots which is eventually supplied to the processing factories through local Foria (brokers).

Unlike other inland closed fishing communities, coastal seas and tidal rivers constitute the key traditional livelihoods assets and the main sources of financial capital to the coastal fishing communities throughout the access to informal and the quasi-formal credit markets (Ulrich et al., 2003; PDO-ICZMP, 2003b; CDSP-II, 2000). The main form of loan is the Dadan. Dadon provider is the key player (i.e. fish trader cum money-lender) in controlling fishing effort and marketing of harvested Galda from the SME area. Other actors of the informal credit markets are the crab depots, fish depots and moneylenders, while the NGOs are considered as the actors of quasi-formal credit market (Ulrich et al., 2003; Hannan, 1996).

Fishers' access to the formal credit market (i.e. scheduled banks) is virtually limited due to their lack of tangible assets, although bank rate is lower than other informal markets. The rate of credit from moneylenders is sometime even lower in areas of strong supply of micro-credits from the NGOs. However, interest rate of micro-credits is also higher (75200\%) than the bank rate (BBS, 1999; Islam, 2002; Grameen Bank, 2001; Ulrich et al., 2003). Alam (2001) reported that more than 500 NGOs were involved in aquaculture and fisheries in Bangladesh targeting over 250,000 households. However, while most NGO programs focus on aquaculture demonstration and training for the poorest segments of rural society, small-scale fishermen find difficulty in obtaining credit facilities. Nandeesha and Alam (2001) reported that about 800 CARE staffs were involved in extending aquaculture activities among 40,000 targeted households of which 20-30\% were involved mostly in mostly rice-fish culture.

As traders are powerful in both market control and socially, browbeaten fishermen through weak loan arrangements with traders actually reflect inefficiencies of the credit system rather than marketing system. Fishing season also affect the demand for wage labor and obviously access to credit. For example, before the start of the main fishing season they need a special attention to face financial crises during off-season generally from May to August (Hannan, 1996). But in the present study, the main fishing season was found during monsoon months from June to September? 


\section{Data and Methodology}

This study was conducted through several field surveys in the SME waters covering three administrative ranges (Figure 1). The SME is located between longitudes $89^{\circ} 00^{\prime} \mathrm{E}$ and $89^{\circ} 55^{\prime} \mathrm{E}$ and latitudes $21^{\circ} 30^{\prime} \mathrm{N}$ and $22^{\circ} 30^{\prime} \mathrm{N}$ at the south-west of Bangladesh, encompassing mouth of the 6 estuaries, and numerous rivers, canals and creeks (Giri and Shrestha, 1996; Viju, 1995).

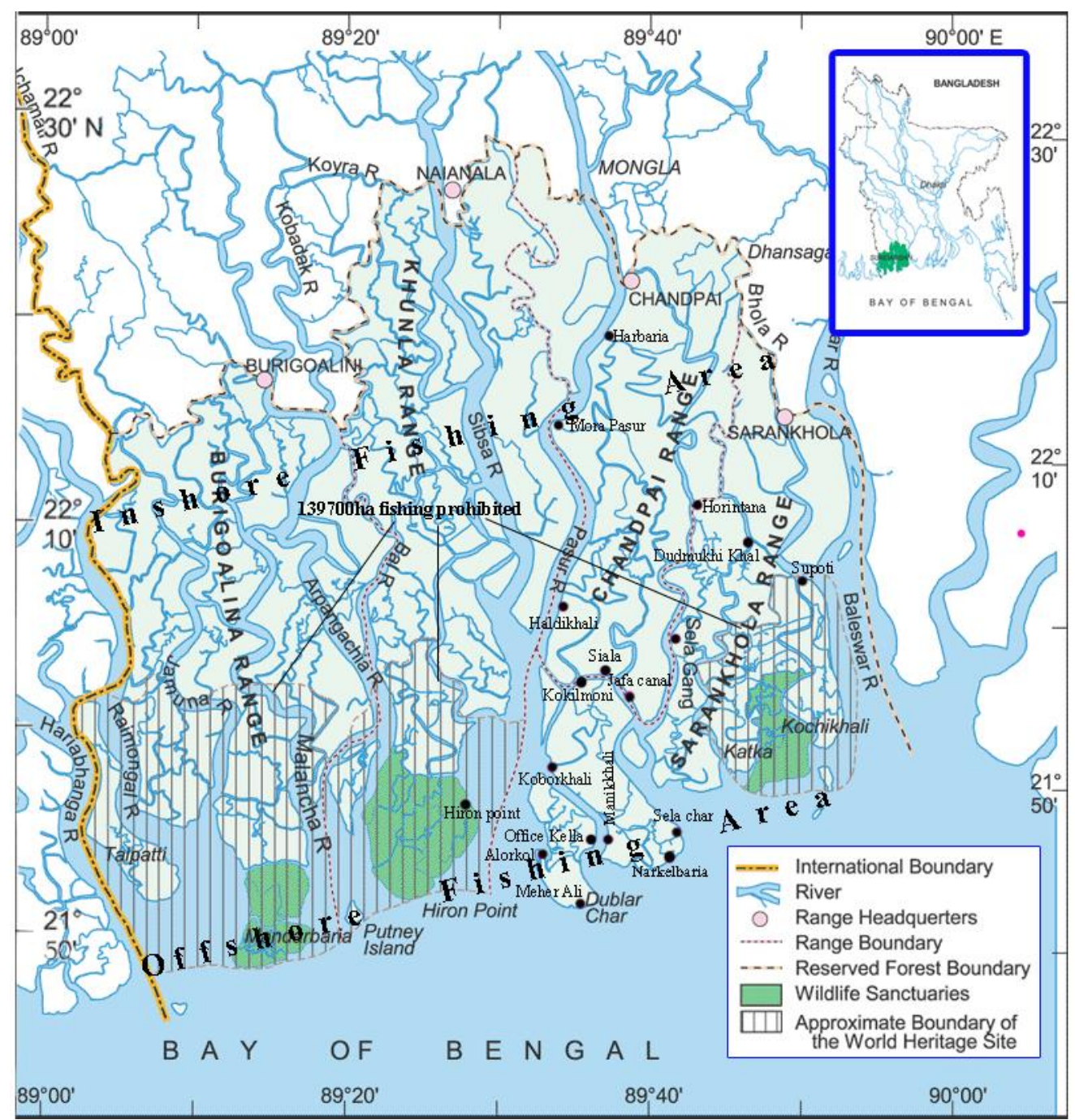

Figure 1: Map of Sundarbans where Range Headquarters are study areas

The study was conducted through 24 individual surveys in the SME of Bangladesh covering 16 river/canals and 32 locations (one-third area) of the Sundarbans along the Mongla-Passure-Dubla area within Sharankhola, Chandpai and Khulna ranges between January and December 2006 at fortnightly interval (Table 1).

Table 1: The GPS locations of the survey areas in the SME

\begin{tabular}{llll}
\hline N Latitude & E Longitude & N Latitude & E Longitude \\
\hline $21^{\circ} 17^{\prime} 08.8^{\prime \prime}$ & $89^{\circ} 34^{\prime} 22.6^{\prime \prime}$ & $21^{\circ} 55^{\prime} 090^{\prime \prime}$ & $89^{\circ} 33^{\prime} 897^{\prime \prime}$ \\
$21^{\circ} 17^{\prime} 11.6^{\prime \prime}$ & $89^{\circ} 38^{\prime} 52.0^{\prime \prime}$ & $21^{\circ} 56^{\prime} 44.4^{\prime \prime}$ & $89^{\circ} 34^{\prime} 59.5^{\prime \prime}$ \\
$21^{\circ} 44^{\prime} 78.4^{\prime \prime}$ & $89^{\circ} 33^{\prime} 27.6^{\prime \prime}$ & $22^{\circ} 14^{\prime} 90.7^{\prime \prime}$ & $89^{\circ} 36^{\prime} 32.4^{\prime \prime}$
\end{tabular}




\begin{tabular}{llll}
$21^{\circ} 45^{\prime} 15.0^{\prime \prime}$ & $89^{\circ} 32^{\prime} 51.8^{\prime \prime}$ & $22^{\circ} 37^{\prime} 11.6^{\prime \prime}$ & $89^{\circ} 29^{\prime} 96.7^{\prime \prime}$ \\
$21^{\circ} 46^{\prime} 09.8^{\prime \prime}$ & $89^{\circ} 32^{\prime} 52.2^{\prime \prime}$ & & \\
\hline
\end{tabular}

The data were collected by direct interviews of randomly selected 1,989 fishermen from 545 non-mechanized boats and 1,428 active gears from eight types of gear. The data were analyzed through descriptive statistics (mean, range, standard deviation) by using SPSS software. The monthly variation in abundance of Galda was estimated by using one-way ANOVA.

\section{Records of Harvesting Galda Fish from SME}

The productions of Galda from the artisanal fishery inside the SME are recorded by the Department of Forest (DoF), Bangladesh. Total SME annual production showed marked variation between years, being the highest $(290,431.60 \mathrm{~kg})$ in 2001 and the lowest $(110,515$ $\mathrm{kg}$ ) in 2002 (Figure 2). After 2002, the production increased steadily up to 2004. Among the four administrative ranges, the mean yearly production volumes from Khulna range were significantly higher $(105,360 \pm 59,419 \mathrm{~kg} / \mathrm{yr})$ than Satkhira $(44,165 \pm 18,548)$, Chandpai $(22,532 \pm 6,593)$ or Sharankhola $(21,910 \pm 7,364)$. Figure 3 indicates a significant effect of geographic location on production of Galda in the SME. However, there were marked variation in number of fishing gears, boats and fishers among the ranges.

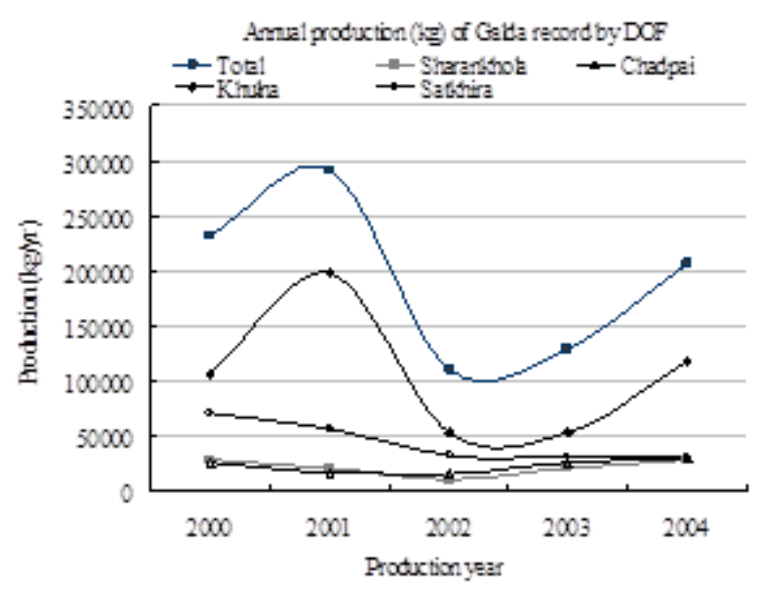

Figure 2: The annual production $(\mathrm{kg} / \mathrm{yr})$ of Galda from the SME Source: compilation from DoF 2005, 2006, 2008a, 2008b

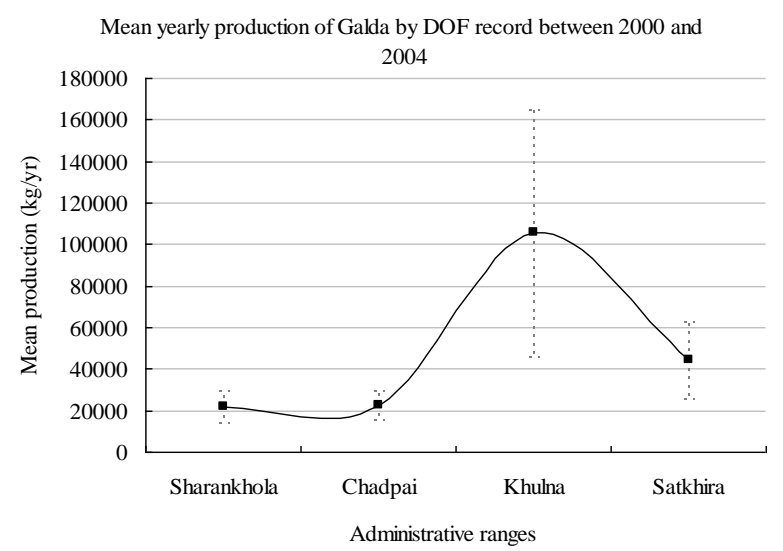

Figure 3: Mean yearly production (kg/yr) of Galda from Four administrative ranges of the SME 
Among different months, the highest production $(296478 \pm 10675 \mathrm{~kg}$ ) was recorded in January and the lowest in July $(59750 \pm 4413 \mathrm{~kg})$. After January, the production rate declined steadily until May and thereafter started to increase gradually with a sudden fall in July (recognized as lowest production month). This trend suggests that Dry summer and monsoon seasons are not suitable for good catch of Galda in the SME (Table 2).

Table 2: Mean ( \pm 1 SD) monthly Galda production in the SME during the year 2000-2004

\begin{tabular}{|c|c|c|c|}
\hline Months & $\begin{array}{c}\text { Mean } \\
\text { Production }(\mathrm{Kg})\end{array}$ & Months & $\begin{array}{c}\text { Mean Production } \\
(\mathrm{Kg})\end{array}$ \\
\hline January & $296478 \pm 10675$ & July & $59750 \pm 4413$ \\
\hline February & $246650 \pm 17418$ & August & $78429 \pm 4084$ \\
\hline March & $117194 \pm 7569$ & September & $125916 \pm 7807$ \\
\hline April & $103229 \pm 3836$ & October & $114503 \pm 4476$ \\
\hline May & $83519 \pm 4703$ & November & $122140 \pm 4641$ \\
\hline June & $95981 \pm 5724$ & December & $129928 \pm 7735$ \\
\hline
\end{tabular}

Source: compilation from DoF 2005, 2006, 2008a, 2008b

Although the highest number of fishers (21807) was engaged in fishing in 2000 (Table 3), but the highest production volume was registered for 2001 (Table 4). Comparatively higher numbers of fishers were entered in the Satkhira range (2546 to 7734) than the (Khulna range (4170 to 7063 ), Sharankhola range (2854 to 3893) and Chandpai range (2412 to 3160 ) (Table 3 ). The production data were also compared by geographical locations remarked by administrative ranges. It reveals that Khulna range was the best for

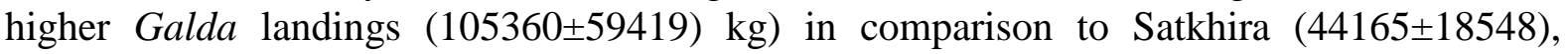
Chadpai (22532 \pm 6593$)$ and Sharankhola (21910 \pm 7364$)$ range.

Table 3: Water area and the number of fisher in four administrative ranges of the SME during 2000-2004

\begin{tabular}{|l|l|l|l|l|l|}
\hline Year/Range & Sharankhola & Chandpai & Khulna & Satkhira & Total \\
\hline Water area (ha) & 39299 & 30006 & 48404 & 55498 & 173207 \\
\hline 2000 & 3850 & 3160 & 7063 & 7734 & 21807 \\
\hline 2001 & 3684 & 3138 & 5850 & 5704 & 18376 \\
\hline 2002 & 3893 & 3023 & 5771 & 5321 & 18007 \\
\hline 2003 & 3017 & 2617 & 5271 & 3405 & 14309 \\
\hline 2004 & 2854 & 2412 & 4170 & 2546 & 11982 \\
\hline $\begin{array}{l}\text { Mean } \pm \\
\text { SD }\end{array}$ & $3459.6 \pm$ & $2870 \pm$ & $5625 \pm$ & $4942 \pm$ & $16896.2 \pm$ \\
\hline
\end{tabular}

Source: compilation from DoF 2005, 2006, 2008a, 2008b

The monthly and daily harvest volume (CPUE) of Galda shrimp from the SME recorded by the Department of Forest between 2000 and 2004 from four administrative ranges are presented in Table 4. The highest mean monthly harvest was recorded from Satkhira range at $16,939 \pm 11734 \mathrm{~kg}$ in 2000 , while the minimum harvest was recorded at 
$883 \pm 3060 \mathrm{~kg}$ from the Chandpai range. The daily CPUE (kg/day) was found to be the highest at $1210 \pm 838 \mathrm{~kg}$ in the Satkhira range in 2000 , followed by $1082 \pm 750 \mathrm{~kg}$ in 2002 from the same range. Both the monthly and daily CPUE were significantly varied among the ranges between 2000 and 2004.

Table 4: The monthly landings and daily CPUE (kg) of Galda harvest from the SME during 2000-2004

\begin{tabular}{|l|l|l|l|l|}
\hline Year & Sharankhola & Chandpai & Khulna & Satkhira \\
\hline & \multicolumn{4}{|l|}{ Harvest volume in $\mathrm{kg}($ Mean \pm SD) } \\
\hline 2000 & $5288 \pm 6337$ & $883 \pm 3060$ & $9320 \pm 4803$ & $16939 \pm 11734$ \\
\hline 2001 & $3978 \pm 5954$ & $1480 \pm 1556$ & $6368 \pm 3503$ & $12461 \pm 10326$ \\
\hline 2002 & $4993 \pm 8162$ & $7367 \pm 7305$ & $4988 \pm 3449$ & $15155 \pm 10497$ \\
\hline 2003 & $2327 \pm 3842$ & $4937 \pm 5304$ & $4227 \pm 2358$ & $7101 \pm 4508$ \\
\hline 2004 & $3136 \pm 3517$ & $4552 \pm 5556$ & $10050 \pm 20055$ & $5592 \pm 4973$ \\
\hline \multicolumn{6}{|l|}{ Daily CPUE in kg Mean $\pm S D)$} \\
\hline 2000 & $378 \pm 453$ & $63 \pm 473$ & $666 \pm 343$ & $1210 \pm 838$ \\
\hline 2001 & $284 \pm 425$ & $106 \pm 110$ & $455 \pm 250$ & $890 \pm 738$ \\
\hline 2002 & $357 \pm 583$ & $526 \pm 522$ & $356 \pm 246$ & $1082 \pm 750$ \\
\hline 2003 & $166 \pm 274$ & $353 \pm 379$ & $302 \pm 168$ & $507 \pm 322$ \\
\hline 2004 & $244 \pm 251$ & $355 \pm 397$ & $783 \pm 1432$ & $436 \pm 355$ \\
\hline
\end{tabular}

Source: compilation from DoF 2005, 2006, 2008a, 2008b

The abundance of Galda $(\mathrm{kg} / \mathrm{ha})$ has been estimated from DoF landing data it was the highest $1.5375 \pm 1.7 \mathrm{~kg} / \mathrm{ha}$ in 2001 and the lowest $0.61 \pm 0.34 \mathrm{~kg} / \mathrm{ha}$ in 2002 (Figure 4). There was a significant variation in mean abundance of Galda between the ranges, being the highest in Khulna $(2.176 \pm 1.23 \mathrm{~kg} / \mathrm{ha})$ and the lowest in Sharankhola $(0.56 \pm 0.19 \mathrm{~kg} / \mathrm{ha})$ range (Figure 4).

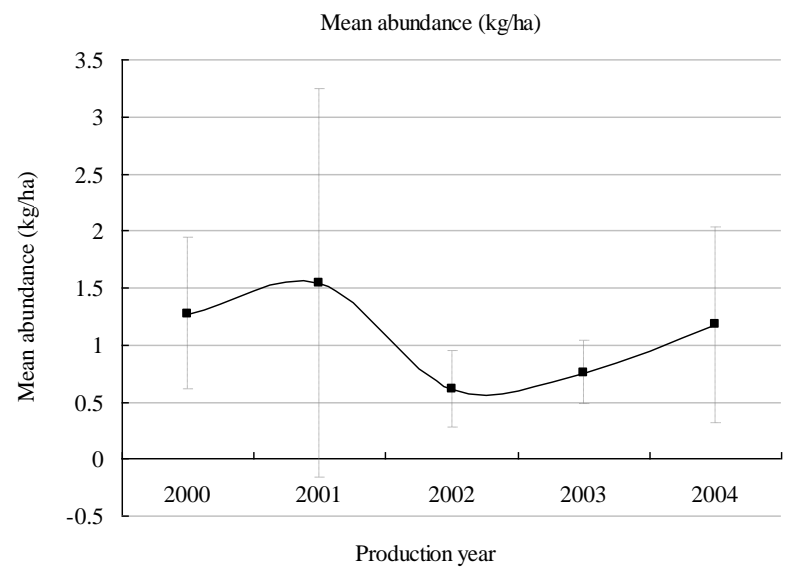

Figure 4: Yearly variation (S.D.) in mean abundance of Galda $(\mathrm{kg} / \mathrm{ha})$ in the SME Source: compilation from DoF 2005, 2006, 2008a, 2008b 


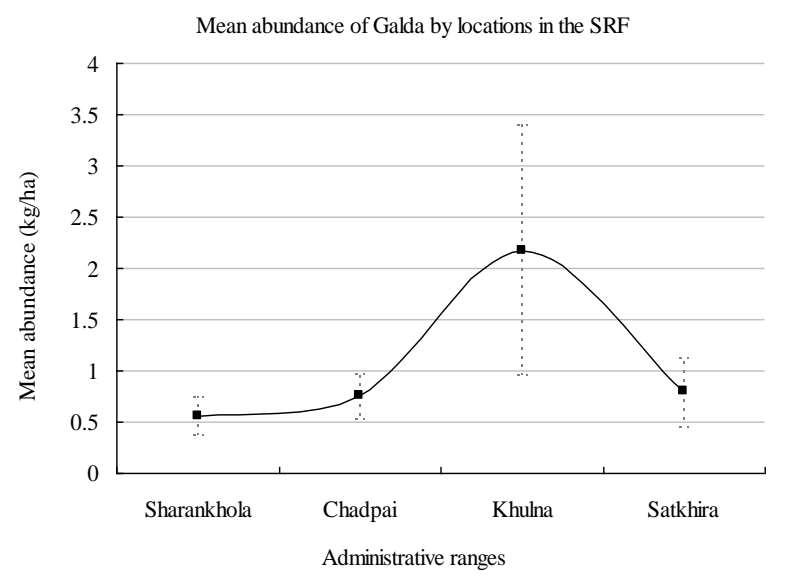

Figure 5: Geographic variation (S.D.) in mean abundance (kg/ha) of Galda in the SME

Source: compilation from DoF 2005, 2006, 2008a, 2008b

The monthly variation in abundance of Galda (kg/ha) has been estimated from DoF landing data. The abundance of Galda varied significantly $(\mathrm{P}<0.05)$ among the months, being the highest in January $(0.34 \pm 0.26 \mathrm{~kg} / \mathrm{ha})$ and the lowest in July $(0.06 \pm 0.08 \mathrm{~kg} / \mathrm{ha})$ (Figure 6). The mean monthly abundance of Galda was the highest in January and fell gradually until July. After July it started to increase until December.

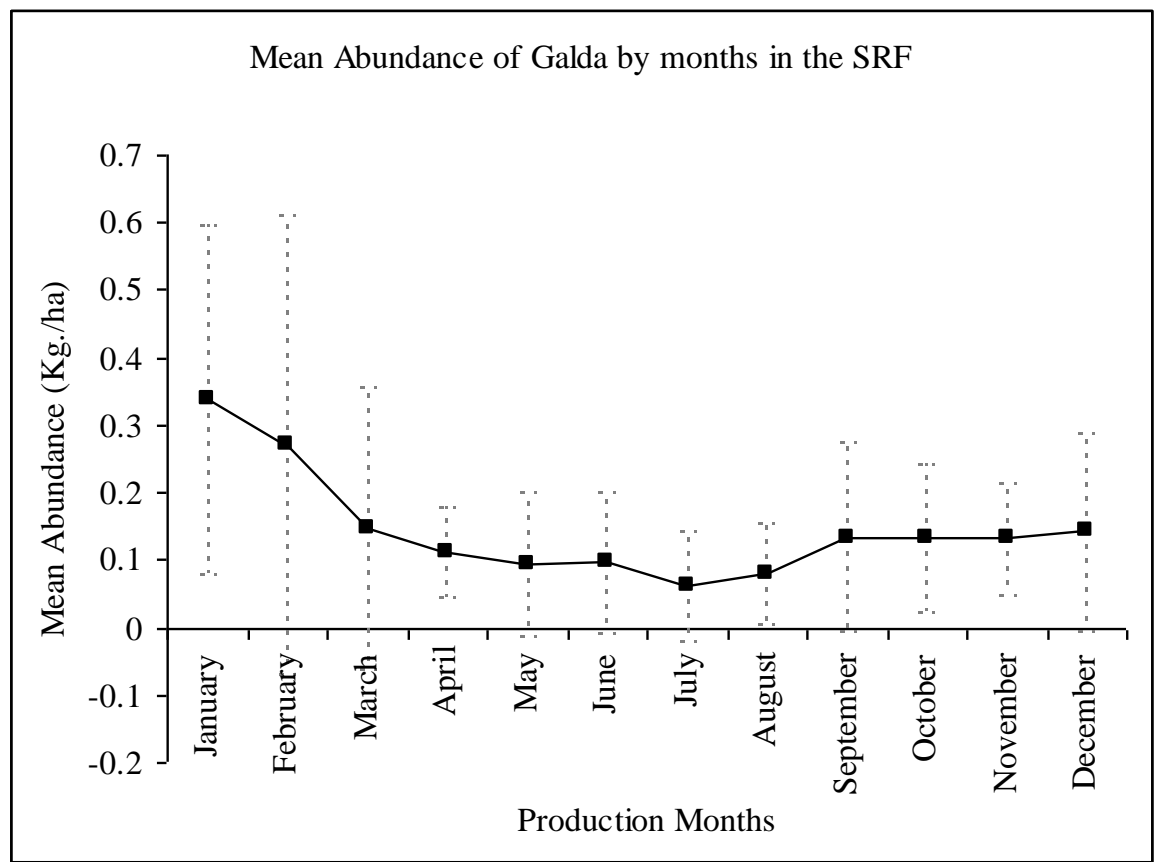

Figure 6: Variation in mean monthly abundance of Galda $(\mathrm{kg} / \mathrm{ha})$ in the SME 
Source: compilation from DoF 2005, 2006, 2008a, 2008b

\section{Structure of Local Market for Selling Galda Fish}

The marketing chain of $M$. rosenbergii caught from the SME is similar to the existing fish marketing channel in the southwest region of Bangladesh. Trading of Galda in the region has been boosted up in recent to meet growing international market demand. As a consequent, the production from aquaculture farm and harvest from natural sources including the SME have been increased steadily over the past few years.

Several categories of fishermen and fish catching enterprises have been identified, namely, (i) fishing labour who work on other's boats only during fishing trip; (ii) fishers with their own boats; (iii) fisher use other's boats in fishing under catch-share agreement with boat owners; and (iv) employed fishers who receive fixed salary from the boat owners. For the $3^{\text {rd }}$ category, boat owners receive the lion share (50-60\%) of the catch. Employed fishers usually receive a wage at BDT 50-100 day ${ }^{-1}$ plus daily meals during fishing on boat. The boat owners may not join in fishing, but can sell the entire catch himself and keep the whole revenues.

The income-sharing arrangement between boat owner and crews varies from area to area. The conditions i.e., covering of operational costs, share distribution according to crew's function etc. observed in the present study agrees well with the findings of Rahman (1993). Crew's functional service also includes catching, drying, transporting and support services, such as cooking. Present study also found that the strong involvement of head fisher, assistant head fisher and laborers with fishing than the boat owners and other fishers, such as cooks, helpers, net makers, repairers. The boat owners' second most important job is business, while other fishers are involved with different occupations for varying periods.

Hussain et al., (1995) reported that boat owner obtains the biggest portion of the catch ( $50-60 \%)$, whilst the crew obtains the remainder. In the present study $40-60 \%$ share is occupied by the boat owners and crews receive salary plus meals paid (BDT 50-100 day $^{-1}$ ) and a part as a bonus depending on the amount of fish caught calculated using an agreed formula. Fishermen-dadandar-aratdar-trader-paikers-dalal-faria-beparies-processing plant authority relationships (Dastidar, 2001; Hussain et al., 1995; Coulter and Disney, 1987; Hill, 1984; Hussain et al., 1995) have exerted a propensity to sell catches at the landing centers (CODEC, 1994; Zafar and Ahsan, 2006). Similar trend has been found in the present study.

Conventionally, a Dadan (advance loan) borrower is bound to sell his catch to his Dadandar (advance loan payer) at prices lower than market prices. Dadondars form the primary market at landing centers. They also play as intermediary traders to sell their purchased goods to the secondary markets. They actually play the role of assemblers at the landing centers (primary markets). They also preformed as the wholesalers who trade goods between secondary and higher secondary markets (i.e. wholesale markets) of the country. In general, paikers (wholesaler) are tied to a limited number of Aratdars (warehouse owner) who provide them loans as working capital. If they have Dadan from an Aratdar, they have to sell/buy their fish through/from him, using him as a commission agent who usually gets 3$6 \%$ commission for his services and costs involved. Part of the commission (2-3\%) may represent an informal form of interest charged by the Aratdars. Moreover, Aratdars play several brokerage functions at the same time. This includes commission agent mentioned above or wholesaler whereby they become the buyer and seller of the commodity (Figure 7).

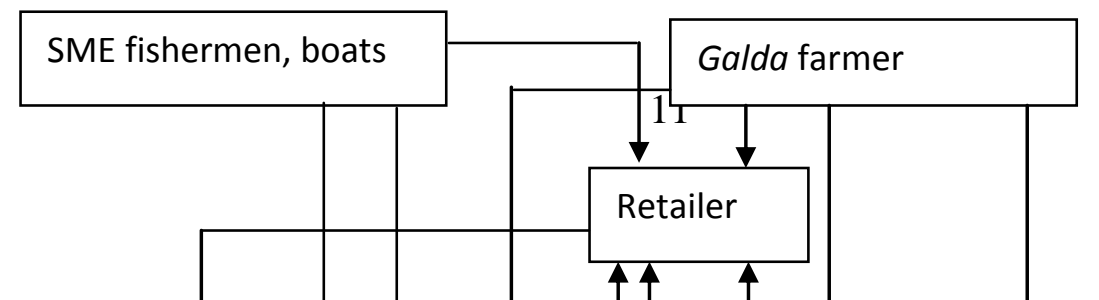


Figure 7: Actors in marketing of Galda in the SME in Bangladesh

\section{Financial Supports for Small Galda Fishers}

The artisanal fishery in the Sundarbans is largely dependent on the supply of credits from various sources. Credits are mainly used to cover purchasing/repairing fishing unit and food costs for the both fishers during a fishing trip and their families at home. The volume of credit received by the fishers varied from BDT 400 to 45,500. However, most of the fisher (36.28\%) had a credit limit between BDT 1,000 and 5,000. Only 3.23\% fishers' had a comparatively larger volume of credit ranged between BDT 10,000 and 15,000 (Table 5).

Table 5: Volume of credit received by the Galda fishers in the SME

\begin{tabular}{|l|l|}
\hline Credit range (BDT ) & $\begin{array}{l}\text { \% of credit holder } \\
\text { (fishermen) }\end{array}$ \\
\hline$<1000$ & 33 \\
\hline $1000-5,000$ & 36.28 \\
\hline $5000-10000$ & 20.9 \\
\hline $10000-15000$ & 3.23 \\
\hline Above 15000 & 6.59 \\
\hline Total & 100 \\
\hline
\end{tabular}

Source: Primary survey 2006

Three types of credits markets, namely- formal, informal and the quasi-formal were found to exist as the source of credit supply to the fishers for operating artisanal fishery in the SME (Table 6). Informal sources were found to be the key players in supplying credits to Galda fishers. Institutions that lend credit or Danon to Galda fishing community included were banks (formal source), NGOs (the quasi-formal source), Dadondar, fish traders and suppliers (fish trader), and broker (Foria, i.e., middlemen in various forms). Among different money lenders, the fish trader-cum-money lender was found to be the key traditional actor for in supplying credit for most of the fishing operations inside the SME. The volume of Dadan depends on economic condition of the fishers and the gear used. The highest $58.63 \%$ fishers received credits from Dadondars. A larger part of the fishers $(23.08 \%)$ collected credits from family enterprise. About $9.19 \%$ fishers receive credit from local money lenders (other than fish traders). Only $7.8 \%$ and $1.3 \%$ fishers received credits from the NGOs and the banks, respectively (Table 6). The conditions for credit were varied by volume and location. Generally a Dadan borrower is obliged to sell his catch to the Dadandar at 20-40\% lower prices than actual market prices which can be considered as informal interest. Most of the money lending organizations was located in the fish trading centers at close proximity of the 
SME. The major Galda trading centers were found at Munshiganj of Satkhira; Rupsh fish market, Nutan Bazar fish market, Koyra and Paikgacha of Khulna; and Mongla, Rampal, Digraj and Soronkhola of Bagerhat district.

Table 6: Credit and suppliers interest rate for the Galda fishers in the SME

\begin{tabular}{|c|c|c|c|c|}
\hline \multirow[t]{2}{*}{ Source } & \multirow{2}{*}{$\begin{array}{l}\% \text { of credit } \\
\text { burrowers }\end{array}$} & \multicolumn{2}{|c|}{ Interest rate $(\%)$} & \multirow[t]{2}{*}{ Location } \\
\hline & & $\begin{array}{l}\text { Mean } \pm \text { SD } \\
\text { (Min.-Max.) }\end{array}$ & $\begin{array}{l}\text { Duration } \\
\text { (months) }\end{array}$ & \\
\hline Bank (SME section) & 1.3 & $\begin{array}{l}13 \pm 2.83 \\
(11-15)\end{array}$ & 12 & $\begin{array}{l}\text { 1. Khulna, } \\
\text { 2. Bagerhat and } \\
\text { 3. Satkhira } \\
\end{array}$ \\
\hline $\begin{array}{l}\text { Local money lender } \\
\text { (other than fish } \\
\text { traders) }\end{array}$ & 9.19 & $\begin{array}{l}86 \pm 23 \\
(70-120)\end{array}$ & $6-12$ & $\begin{array}{l}\text { 1. Khulna: Rupsha Fish Market, Rupsha } \\
\text { Natunbazar and Koira. } \\
\text { 2. Satkhira } \\
\text { 3. Bagerhat: Mongla, Soronkhola } \\
\text { 4. Pirojpur }\end{array}$ \\
\hline $\begin{array}{l}\text { Faria and other } \\
\text { middlemen }\end{array}$ & 6.9 & $\begin{array}{l}32 \pm 10 \\
(19-42)\end{array}$ & Fishing Season & $\begin{array}{l}\text { Thulna: Koira; } \\
\text { 2. Bagerhat: Holdibunia, Mongla, } \\
\text { Digraj, Rampal } \\
\text { 3. Satkhira }\end{array}$ \\
\hline $\begin{array}{l}\text { Multi depot } \\
\text { (fish/crab/shrimp or } \\
\text { Galda) }\end{array}$ & 7.2 & $\begin{array}{l}42 \pm 17 \\
(25-65)\end{array}$ & $\begin{array}{l}\text { Fishing } \\
\text { Season/1-12 }\end{array}$ & 1. Bagerhat: Mongla, Digraj, \\
\hline NGO & 7.8 & $\begin{array}{l}45 \pm 31 \\
(18-76)\end{array}$ & $6-12$ & $\begin{array}{l}\text { 1. Bagerhat: Mongla, Digraj, Joimuni } \\
\text { and } \\
\text { 2. Khulna }\end{array}$ \\
\hline Crab depot & 12.03 & $\begin{array}{l}40 \pm 15 \\
(24-55)\end{array}$ & $\begin{array}{l}\text { Fishing } \\
\text { Season/1-12 }\end{array}$ & $\begin{array}{l}\text { Khulna: Koira } \\
\text { 2. Bagerhat: Holdibunia, Mongla, } \\
\text { Digraj, Rampal } \\
\text { 3. Satkhira }\end{array}$ \\
\hline Fish depot & 13.2 & $\begin{array}{l}40 \pm 15 \\
(24-55)\end{array}$ & $\begin{array}{l}\text { Fishing } \\
\text { Season/1-12 }\end{array}$ & $\begin{array}{l}\text { 1. Khulna: Rupsha Fish Market, Koira } \\
\text { 2. Bagerhat: Mongla, Bagerhat, Joimuni }\end{array}$ \\
\hline Shrimp/Galda depot & 19.3 & $\begin{array}{l}40 \pm 15 \\
(24-55)\end{array}$ & $\begin{array}{l}\text { Fishing } \\
\text { Season/1-12 }\end{array}$ & $\begin{array}{l}\text {. Khulna: Rupsha Fish Market, Rupsha } \\
\text { Natunbazar, Koira; } \\
\text { 2. Bagerhat: Mongla, Joimuni }\end{array}$ \\
\hline $\begin{array}{l}\text { Own (no loan; family } \\
\text { enterprise) }\end{array}$ & 23.08 & 0 & & 1. Family Enterprise \\
\hline Total/ average & 100 & $\begin{array}{l}42.11 \pm 20 \\
(11-120)\end{array}$ & & \\
\hline
\end{tabular}

There was access of fishers to the formal credit markets (i.e. scheduled banks or cooperatives) at $13 \pm 2.83(11-15) \%$ interest. However, the rate of interest offered by the NGOs significant higher (mean: $45 \pm 31$, range: $18-76 \%$ ) than the bank rates. In some remote rural areas, where the number of NGOs are fewer, they charge interest rate as maximum at 47-150\%. While, Foria and local money lenders supply credit at comparatively lower rates $(32 \pm 10,19-42 \%)$ after the formal banks. Trading centers that dealing single species (shrimp, crab, fish or Galda) offere an interest rate of $42 \pm 17$ (25-65) \% while multi-species trading centers offered a comparatively lower rates $(40 \pm 15,55-24 \%$. A number of formalities were found to inhibit fishers to receive credit from Banks and NGOs. For instance, banks and NGOs have a strict time period (6-12 months) to return credit with interest which is absence of in the informal credit markets. Comparatively longer processing time (1-6 months) in issuing credit by the formal sources was found another vital factor that also inhibits fishers to receive credits from these sources. 
It is also evident from the present study that the 'exploitation' of fishers was mainly due to the weak loan agreements between the fishers and traders. This indicates the inefficiency of credit system rather than marketing system. However, credit conditions were more favorable to the fishers in the areas closer to the fishing locations than the distant areas. In absence of formal credit sources, there is an informal profit-sharing arrangement in the fishery which varies from area, the type of fishery and the fishing season. For instance, 60$100 \%$ of the value of Galda catch, after covering the operational costs, was taken by the boat and gear owner $(100 \%$ if hired crews are paid by cash). The remaining part $(<40 \%)$ was distributed among the hired fishing labors. The share of the labor also varied by the type of work performed (catching, drying, transporting, cooking on boat etc.).

\section{Market Supports for Small Galda Fishers}

Most of the fishers tend to sell their catch to the collector boats at fishing place within the SME area or at the landing centers. The source of credit, agreement of Dadan, variability in prices, profit distribution agreement between boat/gear owner and the fishing labour, catch volume, and the relation between the fisher and the landing centers (i.e., intimacy and expected market prices) were found to be determinant factors in determining the place for landings of the harvested catches in the study area. About $55 \%$ of the respondent fishers sold their catch at Notun bazar of Khulna district. The rest of the respondents landed their catches equally (18.18\%) at Digraj, Mongla of Bagerhat district and Rupsha wholesale market, Khulna. Only a few fishers $(9.09 \%)$ landed their catches at Joimuni of Bagerhat district.

Although there is international grading system in Galda marketing chain, it was found to vary by location and the level of marketing chain. The wholesaler/Aratder purchase Galda from the supplier or lower intermediaries at different rate or at a common rate but sold at higher rate or grade to the exporters/export suppliers. Generally fishermen sell out their harvested Galda to the local traders at size-weight basis. About $50 \%$ of the harvest were sold at grade $20,<10 \%$ at grade 5 or 10 . The remaining Galda were equally divided between grades 30 and 50. The average landing center price of Galda depends on grade which varied from US\$2.6 to $6.5 \mathrm{~kg}^{-1}$ (Table 7). The international grading and selling prices are presented in the Table 8. The average prices of Galda at landing centers are varied from BDT 290 to $750 \mathrm{~kg}^{-1}$. The average prices of Galda at landing centers and in international markets were BDT 290 and $750 \mathrm{~kg}^{-1}$, respectively in 2006 .

Table 7: Prices of head-on Galda landing center at Southwest region of Bangladesh

\begin{tabular}{|c|c|c|c|c|c|c|}
\hline \multirow[t]{2}{*}{ Grade } & \multirow{2}{*}{$\begin{array}{l}\text { Counts (No. } \\
\text { of head-on } \\
\text { Galda } \mathrm{kg}^{-1} \text { ) }\end{array}$} & \multirow{2}{*}{$\begin{array}{c}\text { Average } \\
\text { weight } \\
\text { (g) }\end{array}$} & \multicolumn{3}{|c|}{ Price $\left(\mathrm{BDT} \mathrm{kg}^{-1}\right)$} & \multirow{2}{*}{$\begin{array}{c}\text { Average } \\
\text { prices } \\
\left(\mathrm{US} \$ \mathrm{~kg}^{-1}\right)\end{array}$} \\
\hline & & & Maximum & Minimum & $\begin{array}{c}\text { Average } \\
\text { prices } \\
\left(\text { BDT kg }^{-1}\right)\end{array}$ & \\
\hline 5 & 5 or less & 200 & 430.50 & 414.50 & 422.50 & 6.50 \\
\hline 10 & $6-10$ & 125 & 351.50 & 337.50 & 344.50 & 5.30 \\
\hline 20 & $11-20$ & 70 & 287.00 & 272.00 & 279.50 & 4.30 \\
\hline 30 & $21-30$ & 40 & 239.00 & 229.00 & 234.00 & 3.60 \\
\hline 50 & $31-50$ & 25 & 171.00 & 167.00 & 169.00 & 2.60 \\
\hline
\end{tabular}

$1 \mathrm{US} \$=$ BDT 65.00 
Table 8: Prices of headless Galda at processing factories in the Southwest region of Bangladesh

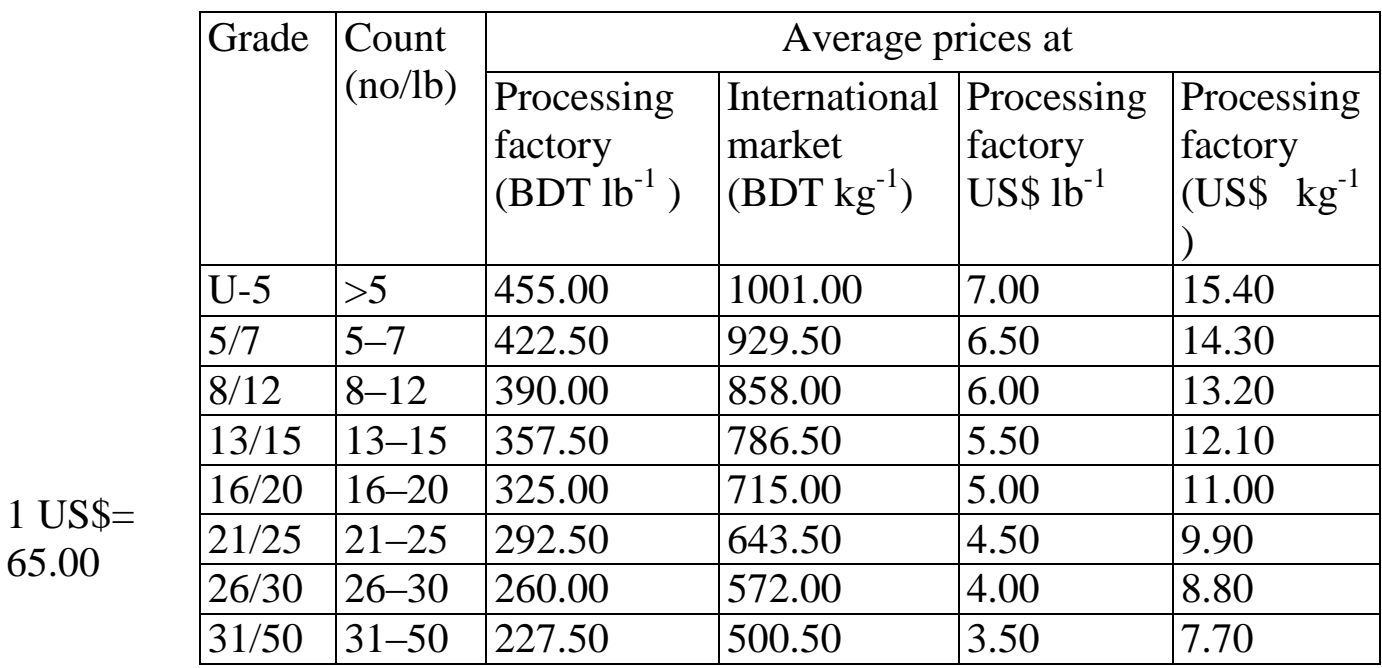

BDT

Local market prices for Galda were found to vary largely by season (Table 9). The rank 1 to 4 indicates prices of Galda in different seasons in descending order. The average maximum price was BDT $430.50 \mathrm{~kg}^{-1}$ during Ashin-Kartik (Sep. to Nov.) followed by the dry (BDT $414 \mathrm{~kg}^{-1}$ ) and winter, pre-winter, wet season (June to September, BDT $337.50 \mathrm{~kg}^{-1}$ ).

Table 9: Price variation in Galda by season in local markets

\begin{tabular}{|l|l|l|l|l|}
\hline \multirow{2}{*}{$\begin{array}{l}\text { Price } \\
\text { variation }\end{array}$} & \multicolumn{4}{|l|}{ Season (higher to lower) } \\
\cline { 2 - 5 } $\begin{array}{l}\text { Higher } \\
\text { prices }\end{array}$ & $\begin{array}{l}\text { September } \\
\text { (Post-Wet) to } \\
\text { November } \\
\text { (Pre-Winter) }\end{array}$ & $\begin{array}{l}\text { December to } \\
\text { February } \\
\text { (dry season) }\end{array}$ & $\begin{array}{l}\text { March and April } \\
\text { (Summer) }\end{array}$ & $\begin{array}{l}\text { December (beginning of dry- } \\
\text { winter), March } \\
\text { (beginning of summer), May } \\
\text { (Pre-winter), June to August } \\
\text { (wet) }\end{array}$ \\
\hline $\begin{array}{l}\text { Lower } \\
\text { prices }\end{array}$ & $\begin{array}{l}\text { June to } \\
\text { August (Wet) }\end{array}$ & $\begin{array}{l}\text { December to } \\
\text { February } \\
\text { (dry season) }\end{array}$ & $\begin{array}{l}\text { February and } \\
\text { March } \\
\text { (Summer) }\end{array}$ & \\
\hline
\end{tabular}

\section{Conclusion and Recommendation}

The study conducted to focus the marketing and financial supports for small-scale artisanal Galda fishery in the SME of Bangladesh. Here, credit flows are not in favor of the fisher. The highest 58.63\% fishers received credits from Dadondars. About 9.19\% fishers received credit from local money lenders. Only $7.8 \%$ and $1.3 \%$ fishers received credits from the NGOs and the banks, respectively.

The Department of Forest is the legal authority in the management of aquatic resources inside the waters of the SME of Bangladesh. The authority should care the sustainable management of small-scale fisheries to ensure a sustainable growth rate of Galda, and protect over exploitation. Proper and easy financial and credit supports is needed for the economic betterment of the small fishers. Proper processing and preserving services are also needed for better price and international market. Government intervention in the Marketing 
channel also needed to avoid many middlemen as well as to reduce the timing gap between catch to preserve.

\section{Acknowledgement}

We are thankful to the The Fisheries and Marine Resource Technology Discipline, Khulna University for the assistance conducting the research. We would also like to thank Professor Dr. Khandakar Anisul Hoq, Professor Dipak Kamal, Mr. Nurul Islam and Mr. Bipul Kumar Nondi for their advices and supports at various stages of the study.

\section{References}

Aftabuzzaman, 1998. Sustainable Environment - Friendly Aqua-culture. In Centre for Policy Dialogue, Environmental Consequences of Export Oriented Shrimp Culture in Bangladesh, CPD Dialogue Report No. 18, Centre for Policy Dialogue, Dhaka, Bangladesh. 78.

Ahmed, N., 2001. Socio-Economic Aspects of Freshwater Prawn Culture Development in Bangladesh. PhD thesis, University of Stirling, UK. 256.

Ahmed, N., 2002. Socio-economic aspects of freshwater prawn culture development in Mymensingh, Bangladesh. International Center for Living Aquatic Resources Management (ICLARM) Report. Dhaka, Bangladesh. 118-122.

Ahmed, N.; Ahammed, F. and Brakel, M.V., 2008. An Economic Analysis of Freshwater Prawn, Macrobrachium rosenbergii, Farming in Mymensingh, Bangladesh. Journal of the World Aquaculture Society, 39(1): 37-50.

Alam, S., 2001. Production, accessibility and consumption patterns of aquaculture products in Bangladesh. In: FAO, 2001. Production, accessibility, marketing and consumption patterns of freshwater aquaculture products in Asia: a cross-country comparison. Rome: Food and Agriculture Organization of the United Nations; 2001. 154-157.

Alam, S.M.N.; Pokrant, B.; Yakupitiyage, A. and Phillips, M.J., 2007. Economic returns of disease-affected extensive shrimp farming in southwest Bangladesh, Aquacult Int. 15:363-370.

Barkat, A. and Roy, P.R., 2001. Marine and Coastal Tenure/Community-based Property Rights in Bangladesh: An overview of resources, and legal and policy developments. Prepared for presentation at the Marine and Coastal Resources and Community-based Property Rights: A Philippine Workshop Organized by Tambuyog Development Centre Tanggol Kalikasan, Centre for International Environmental Law and the CBCRM Resource Centre. 78-82.

BBS, 1999. Population Census 1991, Volume 4, Socio-economic and Demographic Report. Dhaka.

BBS, 2005. "Statistical Yearbook of Bangladesh; 2005", Bangladesh Bureau of Statistics, Statistics Division, Ministry of Planning, Government of the People's Republic of Bangladesh, Dhaka, Bangladesh.

BCAS, 2001. The costs and benefits of bagda shrimp farming in Bangladesh - an economic, financial and livelihoods assessment. Prepared as part of the Fourth Fisheries Project by Bangladesh Centre for Advanced Studies. August 2001.

Bhattacharya, D.; Rahman, M. and Khatun, F.A., 1999a. Environmental Impact of Trade Liberalization and Policies for the Sustainable Management of Natural Resources: A Case Study on Bangladesh's Shrimp Farming Industry, Centre for Policy Dialogue (CPD), Dhaka, Bangladesh. 
Bhattacharya, D.; Rahman, M. and Khatun, F.A., 1999b. Environmental Impact of Structural Adjustment Policies: The Case of Export Oriented Shrimp Culture in Bangladesh. (CPD), Dhaka, Bangladesh.

Bostock, T.; Greenhalgh, P. and Kleih, U., 2004. Policy Research - Implications of Liberalization of fish Trade for Developing Countries - Synthesis Report. Chatham, UK: Natural Resources Institute. ISBN 085954 560-1.

CDSP-II, 2000. Baseline Survey of Coastal Chars in CDSP Areas 1999-2000. Volume VIII. RDC, 2001, Dhaka.

Chaudhuri, A.B. and Choudhury, A., 1994. Mangroves of the Sundarbans. Vol. 1, India. IUCN, Bangkok, Thailand.

CODEC., 1994. Comprehensive Study on Fish Vendors in Chittagong City, Phase II; Community Development Centre, Chittagong.

Coulter, J.P. and Disney, J.G., 1987. "The Handling, Processing and Marketing of Fish in Bangladesh" ODNRI (Overseas Development Natural Resources Institute) Bulletin No. 1, London, UK.

Dastidar, R., 2001. Literature Review on Fish Distribution from Coastal Communities Market and Credit Access Issues; Paper prepared for workshop on "Poverty Alleviation and Livelihood Security among the Coastal Fishing Communities Market and Credit Access Issues", 27-28 March 2001, Chittagong.

DoF (Department of Fisheries), 2005. Fish Catch Statistics of Bangladesh, Bangladesh Fishery Resources Survey System. BFRSS, Department of Fisheries, Dhaka, Bangladesh.

DoF (Department of Fisheries), 2006. Fish Catch Statistics of Bangladesh, Bangladesh Fishery Resources Survey System. BFRSS, Department of Fisheries, Dhaka, Bangladesh.

DoF (Department of Fisheries), 2008a. Fish Catch Statistics of Bangladesh, Bangladesh Fishery Resources Survey System. BFRSS, Department of Fisheries, Dhaka, Bangladesh.

DoF (Department of Fisheries), 2008b. Fishery Statistical Yearbook of Bangladesh 20062007. Fisheries Resources Service System, Department of Fisheries (DOF), Ministry of Fisheries and Livestock, Dhaka, Bangladesh, 42.

FAO, 2004. Report of the Expert Consultation on the Role of Small-scale Fisheries in Poverty Alleviation and Food Security. FAO Fisheries Report. No. 749, Rome,20 p.

Gain, P., 1998. Bangladesh Environment: Facing the 21st Century.

Giasuddin, M.K. $(E d)$, 2002. Review of the current knowledge on coastal shrimp fry collection and it's impact on biodiversity. Fourth Fisheries Project report -2002 on PL Fishery Management Action Plan, Department of Fisheries, Ministry of Fisheries \& Livestock, Dhaka, Bangladesh, , supported by Global Environment Facility/World Bank under Aquatic Resources Development, Management and Conservation Studies

Giri, C. and Shrestha, S., 1996. Land cover mapping and monitoring from NOAA AVHRR data in Bangladesh. International Journal of Remote Sensing, 17 (14): 2749-2759.

Grameen Bank, 2001. Annual Report 2001. Dhaka.

Guha, Bakshi, D.N., Sanyal, P. and Naskar, K.R. (Eds.), 1999. Sundarbans Mangal. Naya Prokash, Calcutta, 771 pp.

Halim, S.; Hoq, M.E.; Kamal, M. and Wahab, M.A., 2001. Feasibility study for the shrimp component of the Fourth Fisheries Project: Women and children study. Prepared by Bangladesh Centre for Advanced Studies, Dhaka, July 2001.

Hannan, M., 1996. Rural credit: An Assessment of Sources and Types available in Bangladesh. Information Bulletin 11, DFID/BOBP, Chennai, India, 62 pp. 
Hill, B.J., 1984. Aquaculture of the mudcrab. In: The Potential for Aquaculture in Queensland, Queensland Department of Primary Industries Publication, 29-45.

Hinrichsen, D., 1998. Coastal Waters of the World: Trends, Threas and Strategies. Island Press, USA.

Huda, F.A.; Salehin, M.M. and Khan, M.I., 2002. Economics of Periphyton-Based Aquaculture Production in Bangladesh. On Line Journal of Biological Sciences, 2 (8): 518-519.

Hussain, M. Muzaffar and Uddin, M.H., 1995. Quality Control and Marketing of Fish and Fish Products: Needs for Infrastructure and Legal Support. Paper presented at the National Workshop on Fisheries Resources Development and Management in Bangladesh, Dhaka 29 October - 1 November 1995. MoFL in collaboration with $\mathrm{BOBP} / \mathrm{FAO}$ and ODA.

Hussain, Z. and Acharya, G. (Eds.), 1994. Mangroves of the Sundarbans. Volume 2: Bangladesh. World Conservation Union, Gland, $257 \mathrm{p}$.

Islam, M., 2002. Utilization of Renewable Energies in Bangladesh. Electronic Book -2. Dhaka: Shakti: Energy website of Bangladesh (URL: http://shakti.hypermart.net).

Islam, M.N. (Ed.), 2007. Annual Report, 2005-2006. Department of Fisheries, Ministry of Fisheries \& Livestock, Dhaka, Bangladesh, pp. 32-34.

Islam, M.S. and Wahab, M.A., 2005. A review on the present status and management of mangrove wetland habitat resources in Bangladesh with emphasis on mangrove fisheries and aquaculture. Hydrobiologia, 542: 165-190.

Ito, S., 2002. From rice to prawns: economic transformation and agrarian structure in rural Bangladesh. The Journal of Peasant Studies, 29(2): 47-70.

Karim, A., 1994. Vegetation. Mangroves of the Sundarbans, Vol. 2: Bangladesh (eds. Hussain Z and Acharya G), pp. 43-74. IUCN, Bangkok, Thailand.

Leung, P. and Sharma, K.R. (Eds.).. 2001: Economics and Management of Shrimp and Carp Farming in Asia: A collection of Research Papers based on the ADB/NACA Farm Performance Survey, Network of Aquaculture Centres in Asia-Pacific (NACA), Bangkok, Thailand.

Ling, B.H.; Leung, P.S. and Shang, Y.C., 2001. Comparing Asian Shrimp Farming the Domestic Resource Cost (DRC) Approach. In Leung P.S. and Sharma K.K. (Eds.), Economic and Management of Shrimp and Carp Farming in Asia, Network of Aquaculture Centers in Asia Pacific, Bangkok, Thailand.

Ling, B-H, Leung, P.S. and Shang, Y.C., 1999. Comparing Asian shrimp farming: the domestic resource cost approach. Aquaculture, 175: 31-48.

Manju., 1996; Nijera Kori, 1996; cited in/summarised by UNEP. 1999. Environmental Impacts of Trade Liberalization and Policies for the Sustainable Management of Natural Resources: A Case Study on Bangladesh's Shrimp Farming Industry. United Nations Environment Programme, New York and Geneva, 1999.

Naskar, K.R. and Guhabakshi, D.N., 1987. Mangrove Swamps of the Sundarbans - An Ecological Perspective. Naya Prokash, Calcutta, 263 p.

PDO-ICZMP, 2003b. Coastal Livelihoods-situation and context, Working Paper WP015, Dhaka, Bangladesh.

Primavera, J.H., 1995. Mangroves and brackishwater pond culture in the Philippines. Hydrobiologia, 295: 303-309.

Primavera, J.H., 1997. Socio-economic impacts of shrimp culture in Aquaculture Research. Vol. 28, pp. 815-827. South-East Asian Fisheries Development Centre, Ilolio, Philippines.

Quddus, A.H.G.; Rutherford, S. and Phillips, M., 2001. Final Report on Livelihood Analysis under Shrimp Sector. Social Feasibility Studies of the Fourth Fisheries Project. 
Rahman, A.K.A., 1993. Marine small scale fisheries in Bangladesh. Regional Office for Asia and the Pacific, Bangkok, 55 pp.

Rahman, M.M.; Chowdhury, Z.A. and Sada, M.N.U., 2003. Coastal resources management, policy and planning in Bangladesh, pp. 689-756. In: G. Silvestre, L. Garces, I. Stobutzki, M. Ahmed, R.A. Valmonte-Santos, C. Luna, L. Lachica-Aliño, P. Munro, V. Christensen and D. Pauly (Eds.) Assessment, Management and Future Directions for Coastal Fisheries in Asian Countries. WorldFish Center Conference Proceeding, 67: 1-120.

Rollet, B., 1981. Bibliography on Mangrove Research 1600-1975. UNESCO, Paris, 479 pp.

Ronnback, P., 1999. The Ecological Basis for Economic Value of Seafood Production Supported by Mangrove Ecosystems. Ecological Economics, 29: 235-252.

Ronnback, P., 2001. Shrimp Aquaculture - State of the Art. Swedish EIA Centre, Report 1. Swedish University of Agricultural Sciences (SLU), Uppsala.

Rouf, M.A. and Jensen, K.R., 2001. Coastal Fisheries management and Community Livelihood. Possible Strategy for the Sundarbans, Bangladesh, ITCZM Monograph No. 04, Series 2001.

Rutherford, S., 1994. CARE and Gher: Financing the Small Fry. Report prepared for CARE International in Bangladesh with support from the Bangladesh Aquaculture and Fisheries Resource Unit (BAFRU).

Seidensticker, J. and Hai, M.A., 1983. The Sundarbans wildlife management plan: conservation in the Bangladesh coastal zone. International Union for the Conservation of Nature and Natural Resources, Gland, 120 pp.

Shah, W.A.; Phillips, M.; Kamal, S.; Jahan, I. and Sarker, J., 2000. The Economics of Bagda Shrimp (Penaeus Monodon) Farming in Coastal Areas of Bangladesh. In: Sen S (Ed.), Grassroots Voice Volume-III, (Issues I \& II), Bangladesh Resource Centre for Indigenous Knowledge, Dhaka, Bangladesh.

Shang, Y.C.; Leung, P.S. and Ling, B.H., 2001. Comparative Economics of Shrimp Farming in Asia. In: Leung P.S. and Sharma K.K. (Eds.), Economic and Management of Shrimp and Carp Farming in Asia. Network of Aquaculture Centres in Asia-Pacific, Bangkok, Thailand.

Thomas, M.A.; Macfadyen, G. and Chowdhury, S., 2001. The costs and Benefits of Bagda Shrimp Farming in Bangladesh. Bangladesh Centre for Advanced Studies, Dhaka, Bangladesh.

Tsai, C-F, Ali, M.Y., 1997. Open-water fisheries of Bangladesh. Dhaka: University Press, $212 \mathrm{pp}$.

Ulrich, K.; Alam, K.; Dastidar, R.; Dutta, U., Oudwater, N. and Ward, A., 2003. Livelihoods in coastal fishing communities, and the marine fish marketing system of Bangladesh. Report of Project "Fish Distribution from Coastal Communities -Market and Credit Access Issues" Project A1004, NRI Report No. 2712.

UNEP, 1999. Environmental Impacts of Trade Liberalization and Policies for the Sustainable Management of Natural Resources: A Case Study on Bangladesh's Shrimp Farming Industry. United Nations Environment Programme, New York and Geneva.

Vannuccini, S., 1999. The Bangladeshi Shrimp Industry. URL: http://www.fao.org/fi/globe/ blogfish/fishery/globefi/doc/presenta/bangle.

Viju, I.C. 1995. Issues in the management of the environment and natural resources in Bangladesh. Journal of Environmental Management, 45 (4): 319-332.

WB, 2006 (World Bank). Bangladesh Fisheries Sector Review. Document of the World Bank, FAP 12/13 project, Report No. 8830-bd.

Willams, D., 2003. Freshwater prawn farming in Bangladesh. Fish Farmer, 26(5): 24-27. 
Zafar, M. and Ahsan. M.N., 2006. Marketing and Value Chain Analysis of Mud Crab (Scylla sp.) in the Coastal Communities of Bangladesh, Research Project Final Report, funded by AFGRP, DFID and BFRF, Dhaka, Bangladesh, pp. 30-61. 